\title{
EFFECT OF NAPHTHA ON BLENDING ALCOHOL DIESEL FUEL ON C.I. ENGINE PERFORMANCE
}

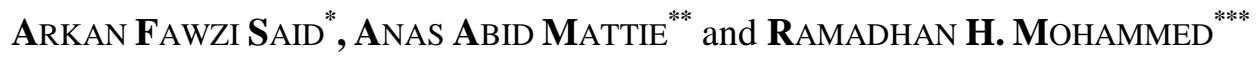 \\ "Dept. of Mechanical Engineering, College of Engineering, University of Duhok, Kurdistan Region-Iraq \\ *** Dept. of Mechanical Engineering,Technical Institute,University of Polytechnique,Kurdistan Region-Iraq \\ ${ }^{* * * * *}$ Faculty Member, University of Duhok, Kurdistan Region-Iraq
}

(Received: July 3, 2017; Accepted for publication: September 11, 2017)

\begin{abstract}
A comparison of diesel engine performance landmarks when blending ethanol alcohol and Naphtha as assistant factor with diesel fuel had been experimentally made. The used blending ratio is $5 \%$ Naphtha, $90 \%$ pure Gas oil and 5\% ethanol alcohol. The exhaust temperature has been decreased, and the fuel consumption seen to be less accompanied with increasing in energy due to ability of blend to burn completely, which yields lower economic point, in addition to the brake thermal efficiency and Air/Fuel ratio increased in mixed fuel with increasing the engine speed, which means an enhancement in operating performance.
\end{abstract}

KEYWORD: Naphtha, Ethanol Alcohol, C.I. Engine performance, Blended fuel.

\section{INTRODUCTION}

T The internal combustion features of Ethanol \& Methanol Alcohol compared with gasoline combustion alone are: the thermal value of Alcohol is less than that of gasoline which is half the thermal value of gasoline, the air amount required for Alcohol burning is half that required for gasoline burning. The vaporizing heat for Alcohol is higher relatively and reach third time that of gasoline, this lead to best cooling of Air/fuel charge and decreasing the high temperature of the engine, Alcohol has highoctane No. about (98-99), so it tends to lift the octane No. of gasoline when blend with it, as an example; when blend $20 \%$ of Methanol with gasoline, the octane no. will increase to approximately (90-98). The exhaust gases of Alcohol make to decrease the pollution due to reducing of $\mathrm{CO}$ gases causes by poor mixture of Alcohol comes from containing of Oxygen in its composition, the amount of NOx in exhaust gas is also less. Alcohols are best solvents for gums, in addition to its higher ability to burn [1].
It has been revealed that combustion of the compression-ignition diesel engine takes place in three main phases such as ignition delay, premixed combustion phase and diffusion combustion phase. The ignition delay period is the time between the start of the injection and the start of combustion, it has an influence on all combustion processes. Many researchers have made the number of experimental research on the use of vegetable oils as fuel in diesel engines, and reported that the high viscosity and low volatility of planting oils resulting in low atomization, slow burning, more smoke emissions and uncontrolled combustion. It is increasing the exhaust gas temperature and NOx reduction with a slight increase in $\mathrm{CO}$ emissions by mixing with vegetable oils such as diesel fuel consumption observed [1]. The use of palm oil as fuel in diesel engines reported that short term use of palm oil significantly increases yield and output levels and prolonged use causes carbon deposits and piston rings sticking [2]. The higher viscosity of biodiesel tends to reduce engine power and engine torque, even the lowest calorific value of biodiesel-fueled, high specific fuel 
consumption results and decreasing temperature of combustion [3]. The use of biodiesel derived from rice bran oil concluded that there is an increase in NOx emissions due to the presence of molecular oxygen in biodiesel [4]. The n-propanol mixture with diesel shows almost the same performance of brake thermal efficiency at low and medium loads, and a higher percentage of n-propanol addition increases the brake thermal efficiency, reducing the brake specific energy consumption at medium and high loads [5]. Experimental results indicate that the addition of $4 \%$ ethanol to diesel fuel increases the engine's output power and efficiency, while reducing the specific fuel consumption for different compression ratios. Greater efficiency was achieved by compression ratio of 21 with an increase ratio of more than $3.5 \%$ [6]. The brake thermal efficiency with fumigation run was lower than diesel [7]. Using $20 \%$ of ethanol as a fumigant can produce an increase about $7.5 \%$ in brake thermal performance [8].

\section{METHODOLOGY}

It is impossible for high density diesel fuel to mix with low density Alcohol unless that the Alcohol should being pure $(100 \%)$ from grays such as water which help to separate the blend, or by using catalytic which help for blending. The process of purifying Alcohol include adding Calcium Chloride to Alcohol then by distillation in order to get pure Alcohol (99-100)\%. Whereas the catalytic used is Naphtha which must be added to Alcohol-diesel fuel to assist for blending due to consisting of several chains of paraffin and aromatics. The experimental investigation was carried out in two stages: the first stage was to test the blends of diesel and Ethanol with and without the additive of Naphtha. Then, the fuels are used to run the diesel engine to test its characteristics of performance. The specification of diesel fuel, Naphtha and Alcohol used is indicated in tables (1).

Table (1): specification of Diesel fuel, Naphtha and Alcohol used:

\begin{tabular}{ccc}
\hline Pure Gas Oil & Naphtha & Alcohol \\
\hline Chemical formula: $\mathrm{C}_{12} \mathrm{H}_{26}$ & Chemical formula: $\mathrm{C}_{16} \mathrm{H}_{34}$ & Chemical formula: $\mathrm{C}_{2} \mathrm{H}_{5} \mathrm{OH}$ \\
\hline Specific density: $0.84 \mathrm{~kg} / \mathrm{m}^{3}$ & Specific density : $0.79 \mathrm{~kg} / \mathrm{m}^{3}$ & Specific density: $0.794 \mathrm{~kg} / \mathrm{m}^{3}$ \\
\hline L.C.V.: $44109 \mathrm{~kJ} / \mathrm{kg}$ & L.C.V.: $46046 \mathrm{~kJ} / \mathrm{kg}$ & L.C.V.: $29800 \mathrm{~kJ} / \mathrm{kg}$ \\
\hline Cetane No.: 42 & Cetane No.: 50 & Octane No.: 99 \\
\hline Boiling temp.: $190-280{ }^{\circ} \mathrm{C}$ & Paraffin (max): $70 \%$ & Boiling temp.: $77.8^{\circ} \mathrm{C}$ \\
\hline & Aromatics (max): $9 \%$ & \\
\hline
\end{tabular}

\section{EXPERIMENTAL OUTFIT}

An amount of Naphtha has been added (50 $\mathrm{cm}^{3}$ ) to pure gas oil with the same amount (50 $\mathrm{cm}^{3}$ ) and blend by mixing. The mixture left for 48 hours to see its possibility of occurring separation of its compositions. Many experiments ratios of both elements has been processed according to the following blending direction, and the best blending values was 5\% Naphtha, $90 \%$ pure gas oil and 5\% Ethanol.

$5 \%$ Naphtha $+90 \%$ Pure gas oil $+5 \%$ Ethanol

Blending direction
V6 - 3.7L FIAT water-cooled engine with compression ratio 17.5 , bore $87.5 \mathrm{~mm}$, and a stroke $110 \mathrm{~mm}$, has been used as shown in figure (1). The engine had operated with above blending without any problem. Several results had been concluded when using pure gas oil and mixed fuel.

Four rotational speeds have been taken under consideration in making our calculations (1200, $1400,1600 \& 1800)$ r.p.m for both cases: pure gas oil and mixed fuel. The torque reading values also specified to be $(40,60,70 \& 80)$ N.m. in case of pure gas oil, and $(20,40,60 \& 80)$ N.m in case of mixed fuel. The consumed fuel volume specified to be $100 \mathrm{~cm}^{3}$, then the fuel consumption 
determined after calculated the required time in seconds to consume above fuel volume by using time gauge. Atmospheric pressure and

\begin{tabular}{lll} 
pressure and & \\
\hline No & Item
\end{tabular}

\begin{tabular}{ll}
\hline 1 & Engine \\
\hline 2 & Dynamometer
\end{tabular}

\begin{tabular}{ll}
2 & Dynamometer \\
\hline 3 & R.P.M. meter
\end{tabular}

\begin{tabular}{cl}
\hline 4 & Lube oil temp. meter \\
\hline 5 & Cooling water inlet pipe \\
\hline 6 & Cooling water flow rate
\end{tabular}

6 Cooling water flow rate measuring tank

\begin{tabular}{cl}
\hline 7 & BOSCH smoke pump \\
\hline 8 & Exhaust gas temp. meter \\
\hline
\end{tabular}

9 Exhaust pressure manometer

10 Water outlet temp. meter

\begin{tabular}{ll}
\hline 11 & Air flow meter \\
\hline 12 & Inlet pressure manometer \\
\hline 13 & Diesel flow line and burette \\
\hline 14 & Fuel pump \\
\hline
\end{tabular}

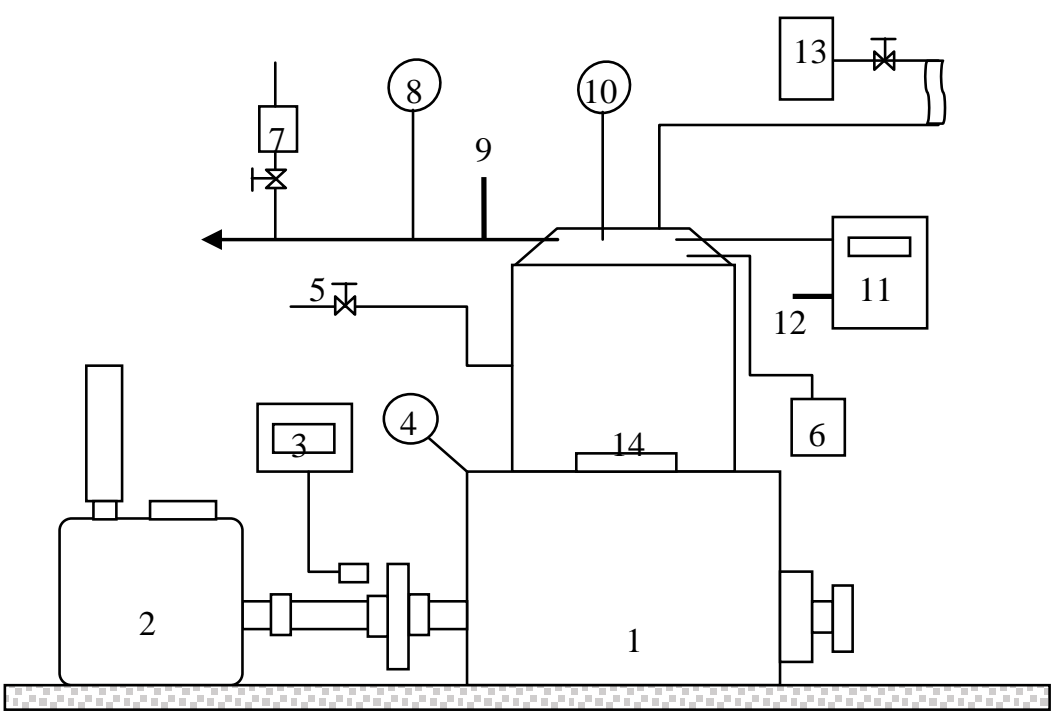

Fig. (1): schematics diagram of the test rig.

\section{Computations}

Brake power has been calculated using the formula [9]:

$$
\text { B.P. }=\frac{2 . \pi \cdot N \cdot T}{60000}
$$

Where;

$\mathrm{N}$ : rotational speed in revolution per minute
T: exerted torque (N.m)

B.P.: brake power in $\mathrm{kW}$.

The amount of consumed fuel $\left(\dot{m}_{f}\right)$ has been determined by the formula:

$\dot{m}_{f}=\frac{\left(V_{f} . S\right)}{(1000 . t)}$ 
Where; $\dot{m}_{f}$ : consumed fuel in $\mathrm{kg} / \mathrm{sec}$. $V_{f}$ : consumed fuel volume in $\mathrm{cm}^{3}$

$S$ : Pure Gas Oil density in $\mathrm{kg} / \mathrm{m}^{3}$ (sec.)

$\mathrm{t}$ : calculated time of fuel consumption

In mixed fuel, $S_{m i x}$. Substituted instead of $S$ which has been evaluated as: $S_{\text {mix }}=\frac{S_{\text {gasoil }}+S_{\text {alcohol }}+S_{\text {naphtha }}}{3}$

Brake Specific Fuel Consumption (b.s.f.c.) in $(\mathrm{kg} / \mathrm{kw} . \mathrm{hr})$ determined by:

b.s.f.c $=\frac{\left(3600 \cdot \dot{m}_{f}\right)}{\text { B.P. }}$

In order to evaluate volumetric efficiency, actual \& theoretical air consumption has been determined using the formulas:

$$
\begin{aligned}
& \left.\dot{m}_{\text {air }}\right)_{\text {act }}=\frac{\left(12 \cdot \sqrt{h_{o}}\right) * \beta_{\text {air }}}{3600} \\
& \left.\dot{m}_{\text {air }}\right)_{\text {theo }}=\frac{\left(V_{s n} * N * \beta_{\text {air }}\right)}{2 * 60}
\end{aligned}
$$

Where; $\dot{m}_{\text {air }}$ : air consumption $(\mathrm{kg} / \mathrm{s})$ $\beta_{\text {air }}$ : air density in $\left(\mathrm{kg} / \mathrm{m}^{3}\right)$, which is calculated by:

$\beta_{\text {air }}=\frac{P_{a t m}}{R^{*} T_{\text {atm }}}$

$V_{s n}:$ Engine Capacity in $\mathrm{cm}^{3}$

$h_{o}$ : water altitude $\left(\mathrm{mm} \mathrm{H}_{2} \mathrm{O}\right)$, used to evaluate the air specific volume.

$\mathrm{P}_{\mathrm{atm}}$. : atmospheric pressure $(\mathrm{kPa})$

$\mathrm{T}_{\mathrm{atm}}:$ : Air temperature $\left({ }^{\circ} \mathrm{C}\right)$

$\mathrm{R} \quad$ : air constant $=287(\mathrm{~J} / \mathrm{kg} . \mathrm{K})$

The Volumetric Efficiency has been evaluated then after by:

$\eta_{v}=\left[\frac{\left.\dot{m}_{\text {air }}\right)_{\text {act }}}{\left.\dot{m}_{\text {air }}\right)_{\text {theo }}}\right] * 100 \%$

Total Power $\left(Q_{t}\right)$ has been calculated by the formula:

$Q_{t}=\dot{m}_{f} *$ L.C.V

Where L.C.V. is low calorific value $(\mathrm{kJ} / \mathrm{kg})$.

Lower calorific value in mixture case has been received according to ratio added to blending fuel as:

L.C.V $)_{\text {mixture }}=\frac{\left(0.9 * \text { L.C. } V_{\text {gasoil }}+0.05 * \text { L.C. } V_{\text {alcohol }}+0.05 * \text { L.C. } V_{\text {naphtha }}\right)}{3}$

Brake \& Indicated thermal efficiencies $\left(\eta_{\text {b.th. }}\right) \&\left(\eta_{\text {I.th) }}\right.$ have been calculated by:

$$
\begin{aligned}
& \eta_{\text {b.th }}=\left[\frac{B . P}{Q_{t}}\right] * 100 \% \\
& \eta_{\text {I.th }}=\left[\frac{I . P}{Q_{t}}\right] * 100 \%
\end{aligned}
$$

Where;

I.P.: is indicated power which is equal to total sum of brake power B.P. and friction power F.P.

Friction power can be determined by Willan's line, where the intersecting point with negative brake power axis represent friction power [9].

Mechanical efficiency can be found as:

$\eta_{m}=\left[\frac{B . P}{I . P}\right] * 100 \%$ by:

The Air to Fuel ratio (A/F) can be determined

$(A / F)=\frac{\left.\dot{m}_{a i r}\right)_{a c t}}{\dot{m}_{f}}$
The temperatures of water entering and out from the engine also has been measured, using temperature gauges, in addition to exhaust temperature $\left(\mathrm{T}_{\mathrm{ex}}\right)$.

\section{RESULTS AND DISCUSSION}

The relation between brake power and fuel consumption has been revealed in figure (2), which represent Willan's line. From this line, we can found friction power which are the friction losses between motive parts, oil pumps loss and cooling water in addition to suction and inject losses of air charge entered. 
In case of pure gas oil fuel, this power increasing gradually with increasing the engine rotational speed, while in blending fuel figure (3) the increasing is not constant or not happened gradually. This was due to fluctuating of engine speed especially at high speeds and low loads, so this lead to unstable increasing in friction power in case of blending.

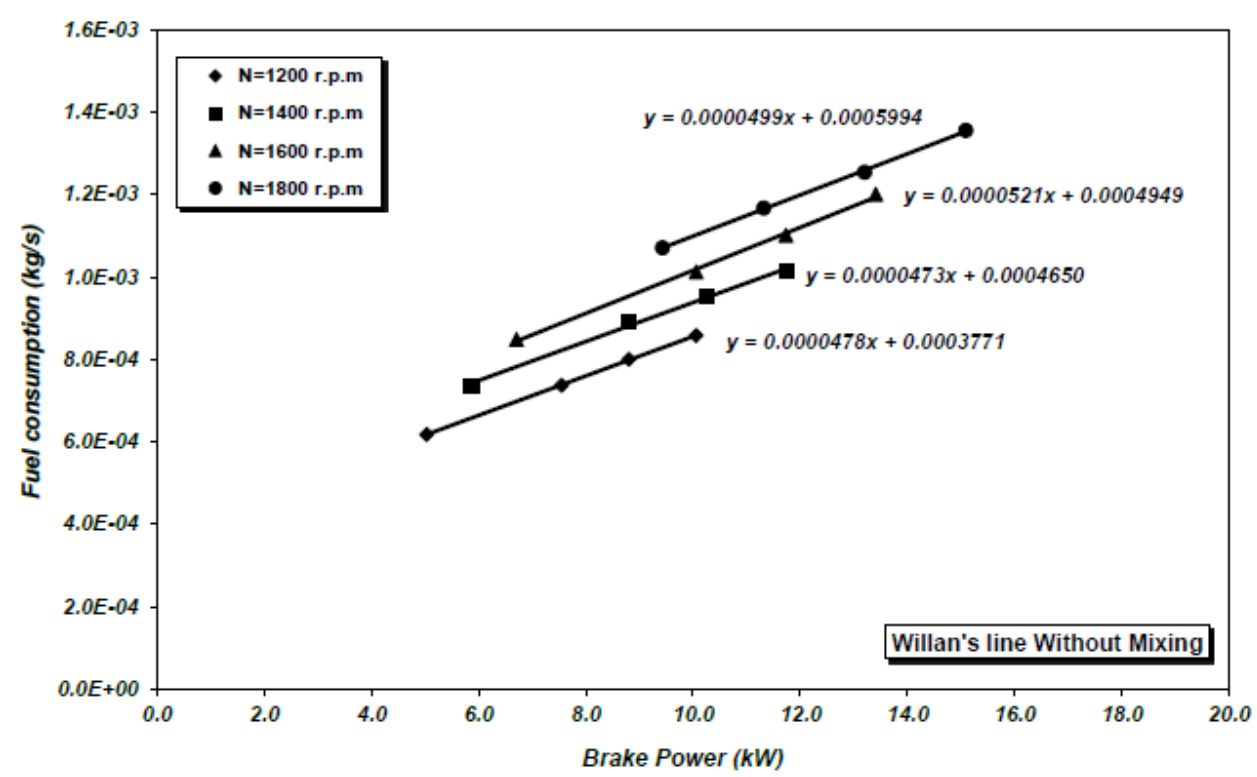

Fig. (2): relation between fuel consumption and brake power for pure gas oil fuel

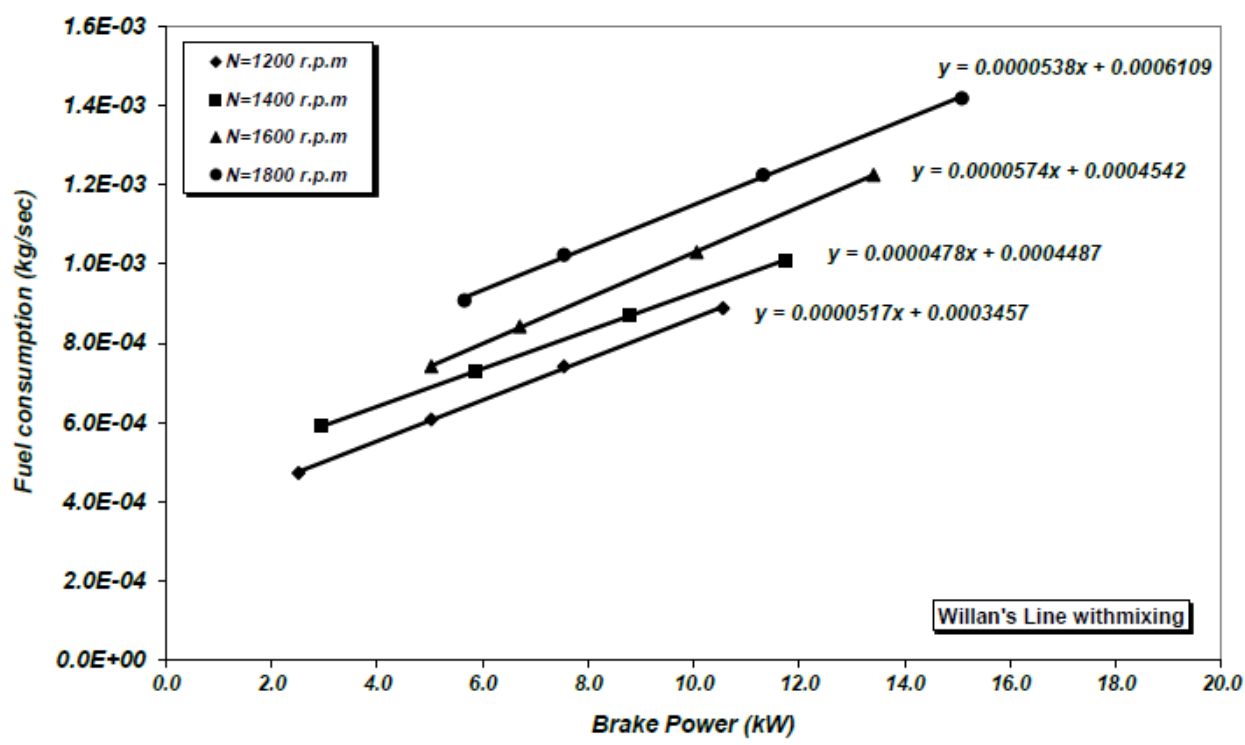

Fig. (3): relation between fuel consumption and brake power for mixing fuel

Performance curves at several speeds are drawn in one graph as shown in figures (4 and 5). The graph shows how specific fuel consumption will change as the brake power changes at a specific speed which called fish hook curve [9]. 


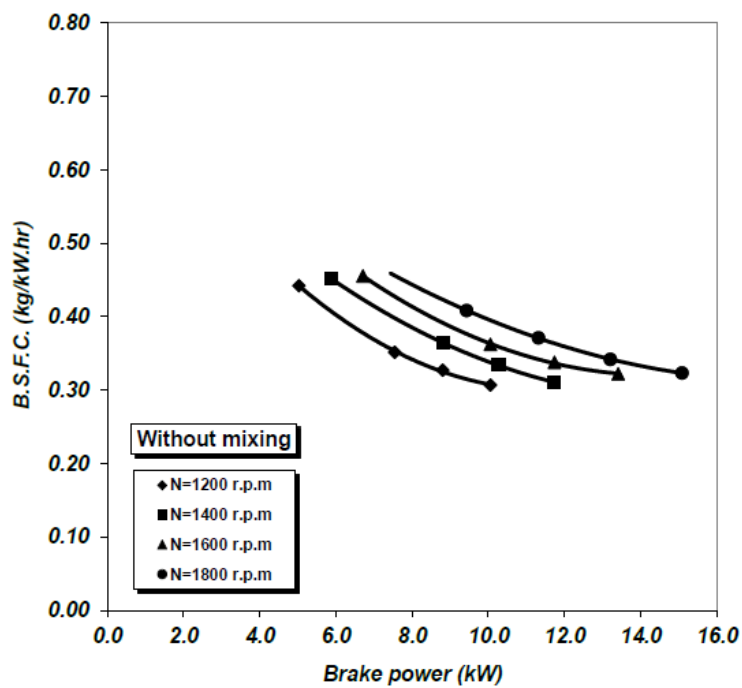

Fig. (4): Fish Hook relation between B.s.f.c. \& B.P. for unmixed fuel and at all speeds

Figures $(6,7,8 \& 9)$ revealed the relationship between brake power and efficiencies without mixing and figures $(10,11,12 \& 13)$ for mixing fuel. It seems clearly that the volumetric efficiency was stable in both cases and at the same speed because it doesn't depend on the fuel type entering the engine, but on the amount of air sucked by the engine. The curved relation of indicated thermal efficiency and brake power has

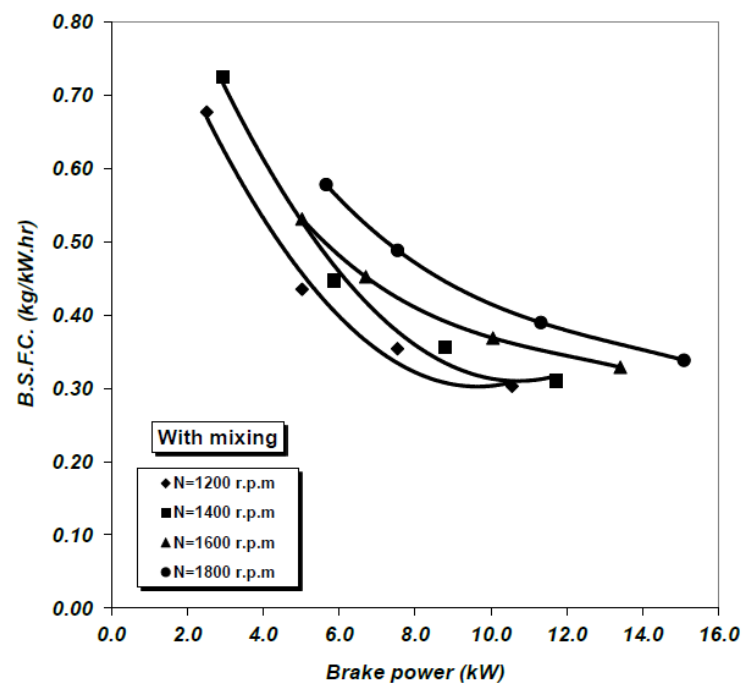

Fig. (5): Fish Hook relation between B.s.f.c. \& B.P. for mixed fuel and at all speeds

seen to increase with increasing brake power and it's larger than the brake thermal efficiency, and this is normally happened due to friction power losses that always cannot be exceeded. The mechanical efficiency seen to be increased with brake power and engine speed increasing, the mechanical efficiency is lower in case of blending fuel than that in case of pure gas oil fuel due to fluctuating

in engine speed.

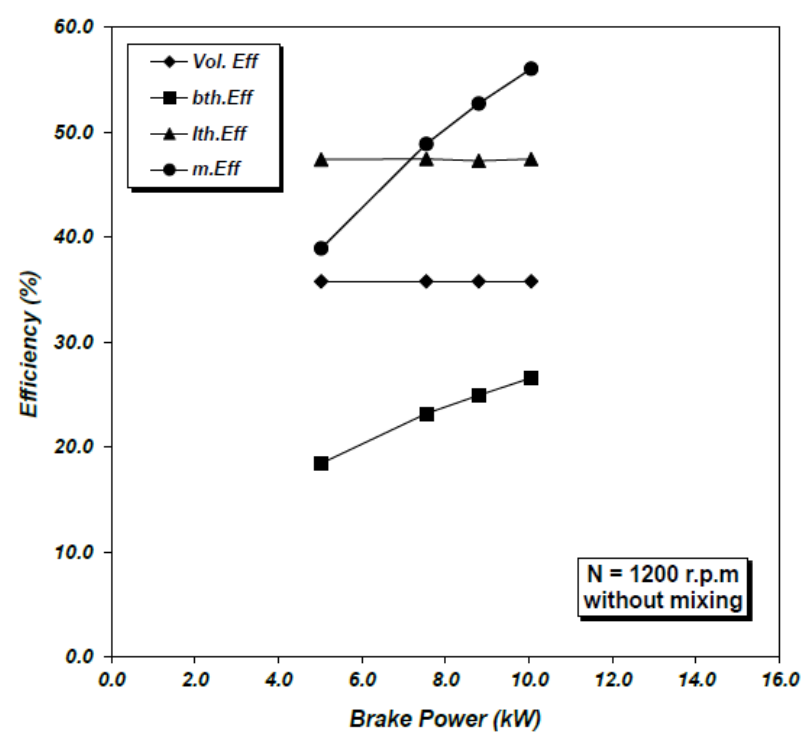

Fig. (6): relation between efficiency and brake power at $\mathrm{N}=1200 \mathrm{rpm}$ without mixing

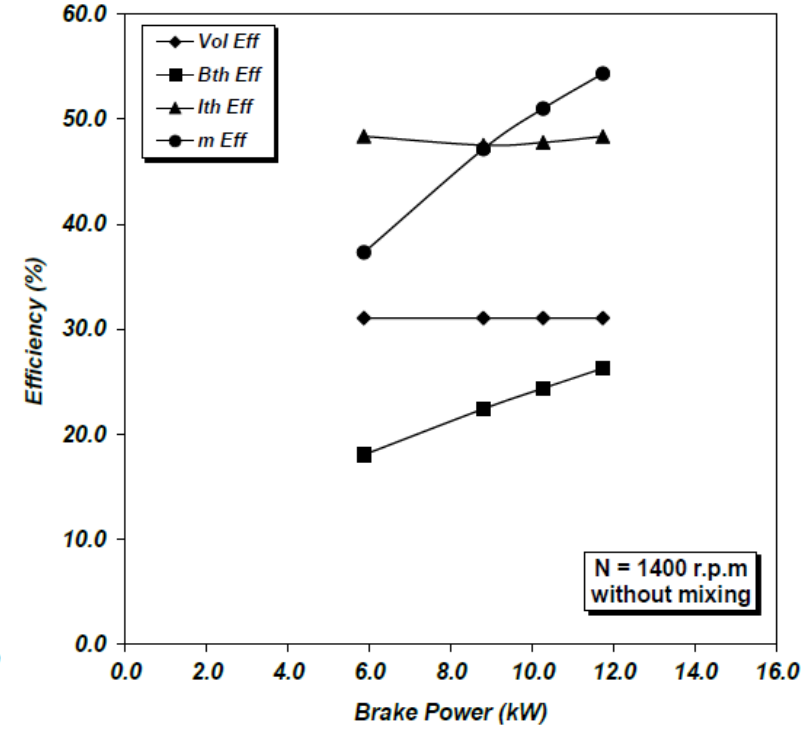

Fig. (7): relation between efficiency and brake power at $\mathrm{N}=1400 \mathrm{rpm}$ without mixing 


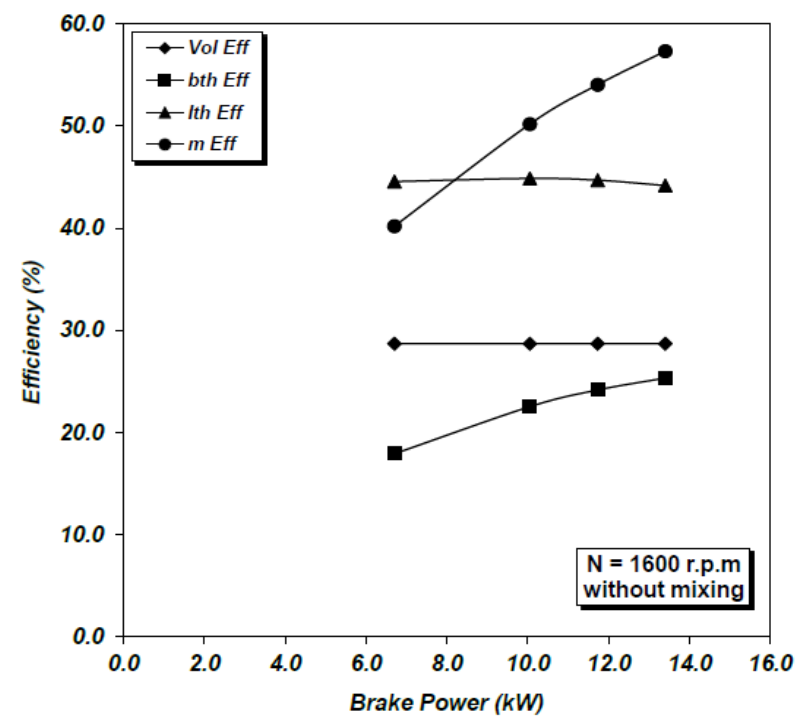

Fig. (8): relation between efficiency and brake power at $\mathrm{N}=1600 \mathrm{rpm}$ without mixing

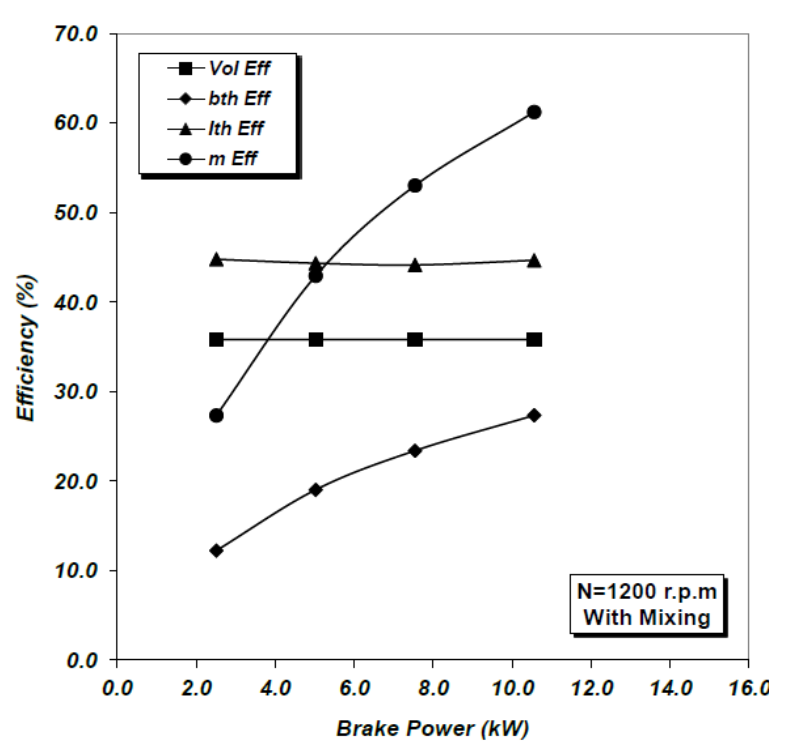

Fig. (10): relation between efficiency and brake power at $\mathrm{N}=1200 \mathrm{rpm}$ with mixing

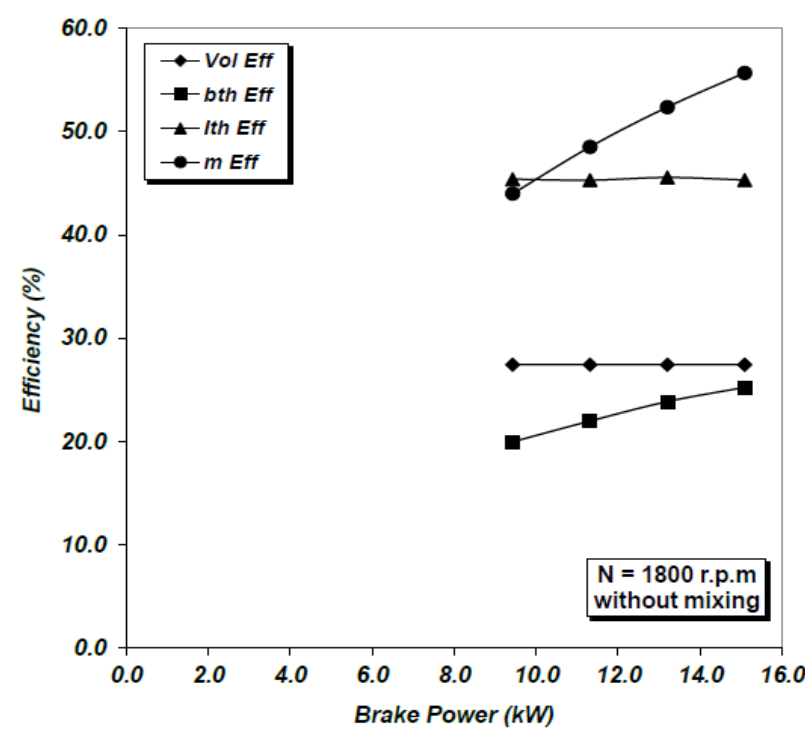

Fig. (9): relation between efficiency and brake power at $\mathrm{N}=1800 \mathrm{rpm}$ without mixing

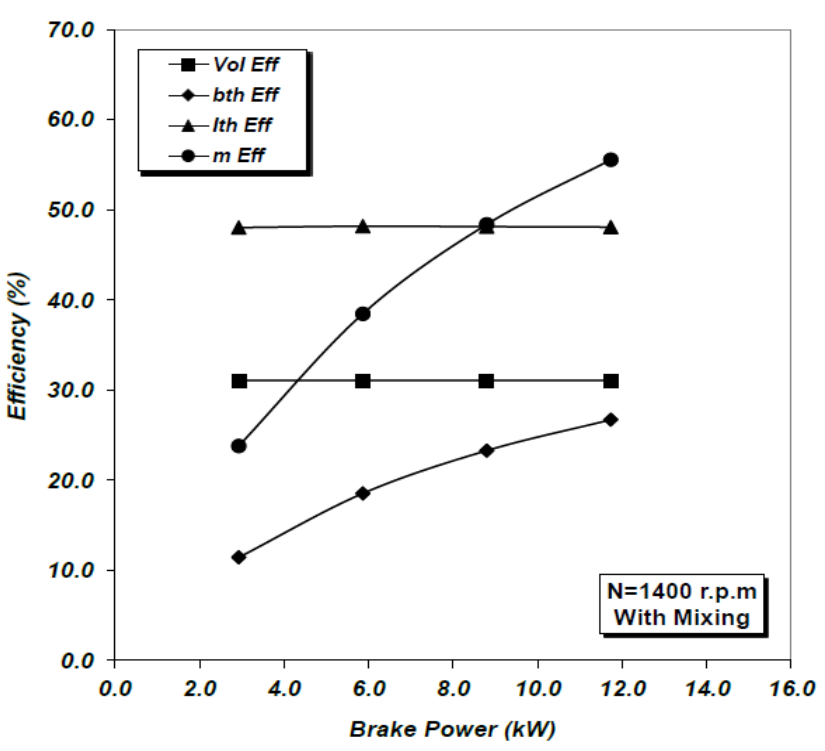

Fig. (11): relation between efficiency and brake power at $\mathrm{N}=1400$ rpm with mixing 


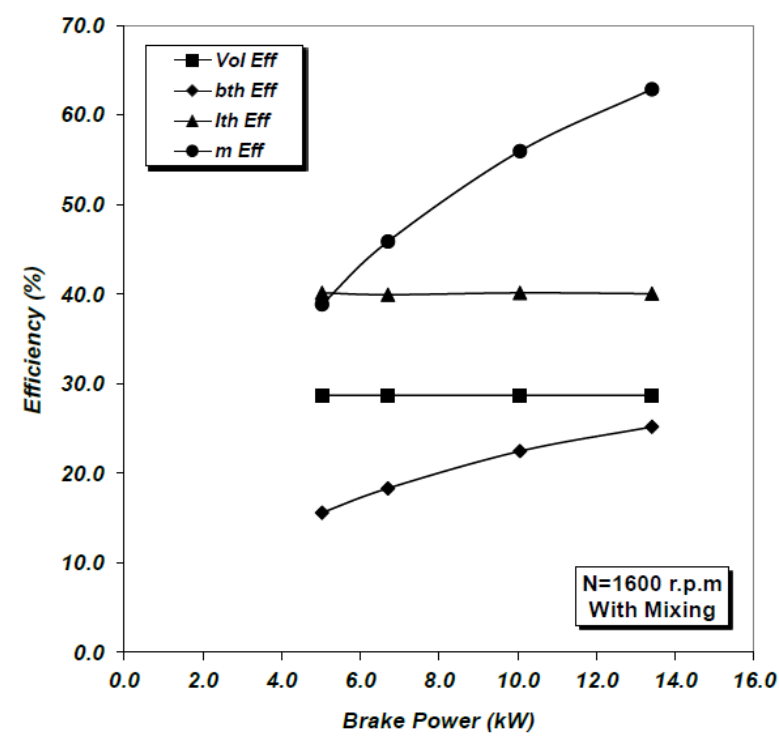

Fig. (12): relation between efficiency and brake power at $\mathrm{N}=1600 \mathrm{rpm}$ with mixing

Figure (14) represents the relationship between brake thermal efficiency and engine speed which can tell an increasing of it in mixed fuel comparing with unmixed fuel. It can be seen that a slight improvement in the efficiency could be noticed when blending diesel fuel with ethanol. The improvement in the thermal efficiency is attributed to the physical and chemical changes

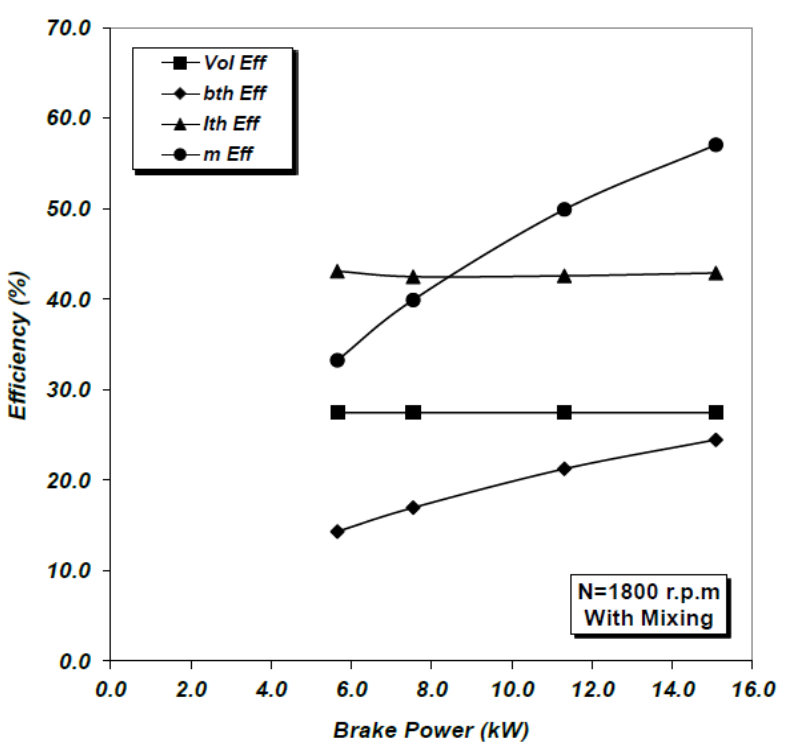

Fig. (13): relation between efficiency and brake power at $\mathrm{N}=1800 \mathrm{rpm}$ with mixing

occurring in the combustion process, this yield to a slight gains in the thermal efficiency due to the increase in the ignition delay. This will produce a rapid rate of energy released which reduces the heat loss from the engine due to lack in time for heat to get out of the cylinder by heat transfer coolant

[8].

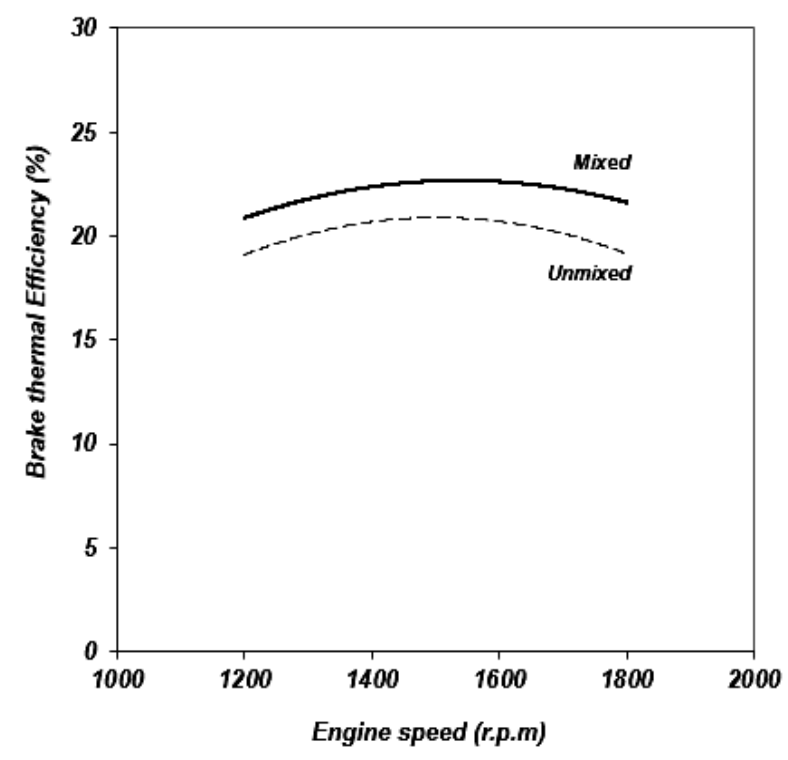

Fig. (14): relation between brake thermal efficiency and engine speed for both mixed and unmixed fuel 
The relation between brake power and exhaust temperatures figure (15) has seen to be proportional, this is due to increasing the loads at a certain speed, because the amount of fuel required has increased to maintain the same engine speed. So this consequently lead to increase peak pressure and temperature inside engine combustion chamber during power stroke. Figures (17, 18, 19 \& 20) indicate this relation for each speed separately and for both cases. In blending fuel figure

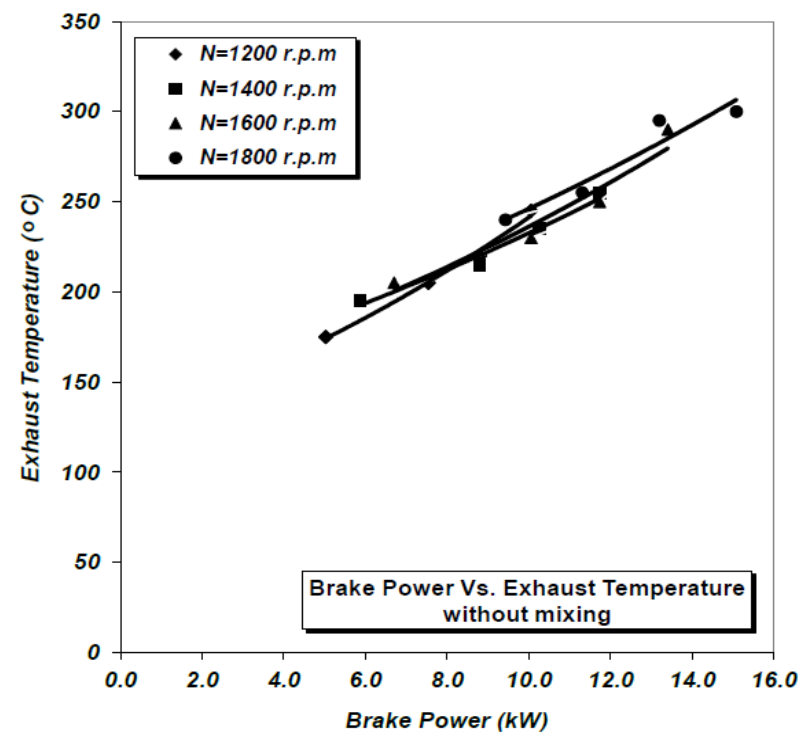

Fig. (15): relation between exhaust temperature and brake power for pure gas oil fuel.

Relations have been obtained of economic point through which we can reach less fuel consumption and larger power, this point is necessary to specify the engine performance. In mixing fuel, we found that the fuel consumption is lower than its value without mixing because of using larger amount of air to burn the mixture. This reflect the ability of mixing fuel to burn completely without fume. Figures $(21,22,23 \& 24)$ indicates the
(16), the exhaust gas temperatures observed to be higher at lower loads, but at medium and high loads, the exhaust gas temperatures is lower than in pure gas oil fuel. The reduction is due to higher latent heat of vaporization of blending elements and the quenching effect of alcohol in the combustion chamber. So the peak temperature and pressure inside combustion chamber in power stroke will be less than without mixing [5].

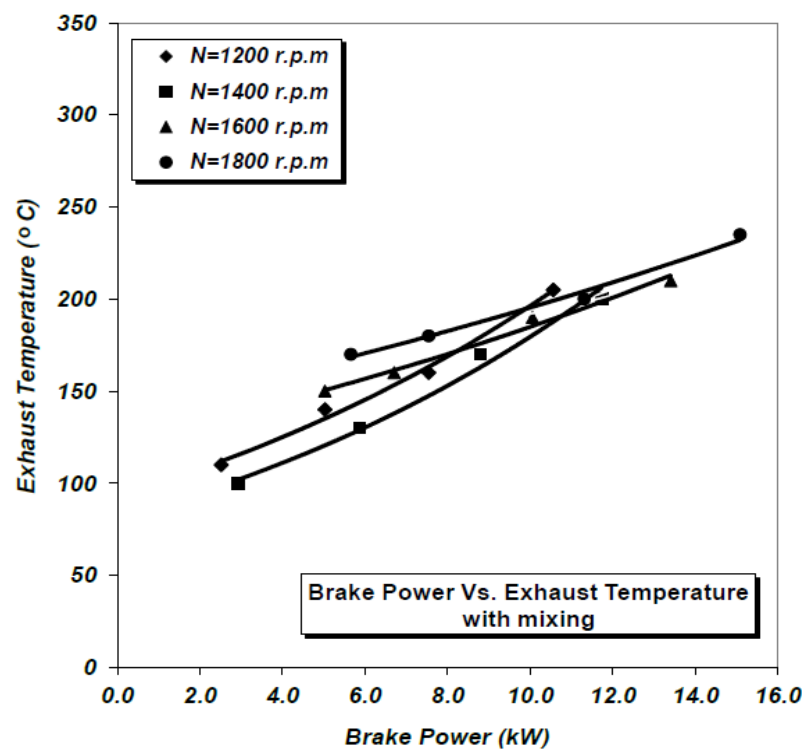

Fig.(16): relation between exhaust temperature and brake power for all speeds and with mixing fuels

relations between fuel consumption and brake specific fuel consumption (B.s.f.c).

Regarding $\mathrm{A} / \mathrm{F}$ ratio in figure (25), it can be observed an increase of the ratio for mixing fuel and this ratio will decrease with increasing brake power resulted from increasing rotational engine speed as shown in figure (26). The reason of this decrease is due to decrease in volumetric efficiency of the engine. 


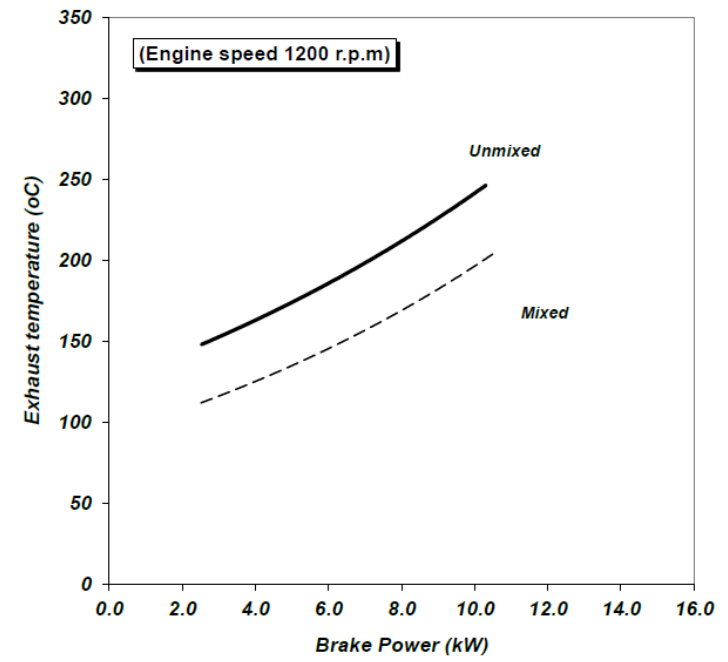

Fig.(17): relation between exhaust temperature and brake power for both mixed and unmixed fuel at $\mathrm{N}=1200 \mathrm{rpm}$

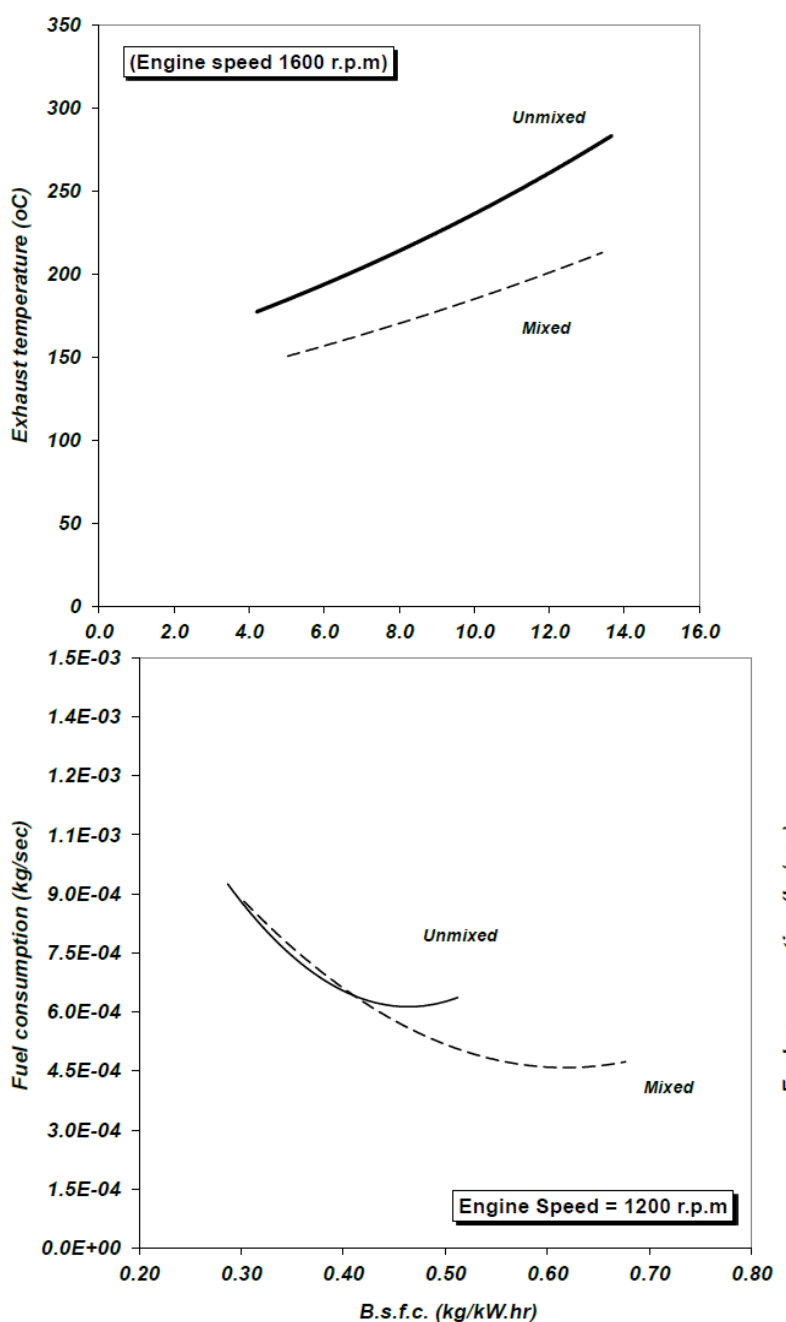

Fig. (21): relation between fuel consumption and brake specific fuel consumption for both mixed and unmixed fuel at $\mathrm{N}=1200 \mathrm{rpm}$

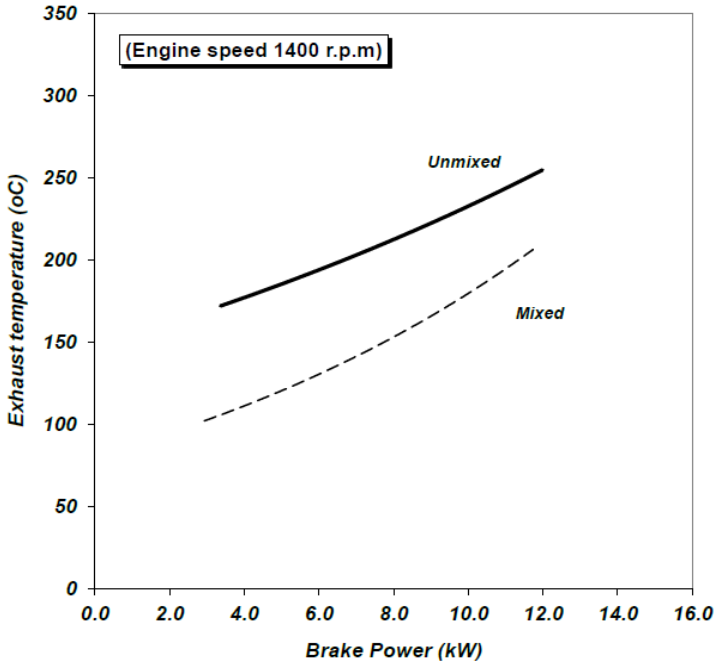

Fig.(18): relation between exhaust temperature and brake power for both mixed and unmixed fuel at $\mathrm{N}=1400 \mathrm{rpm}$

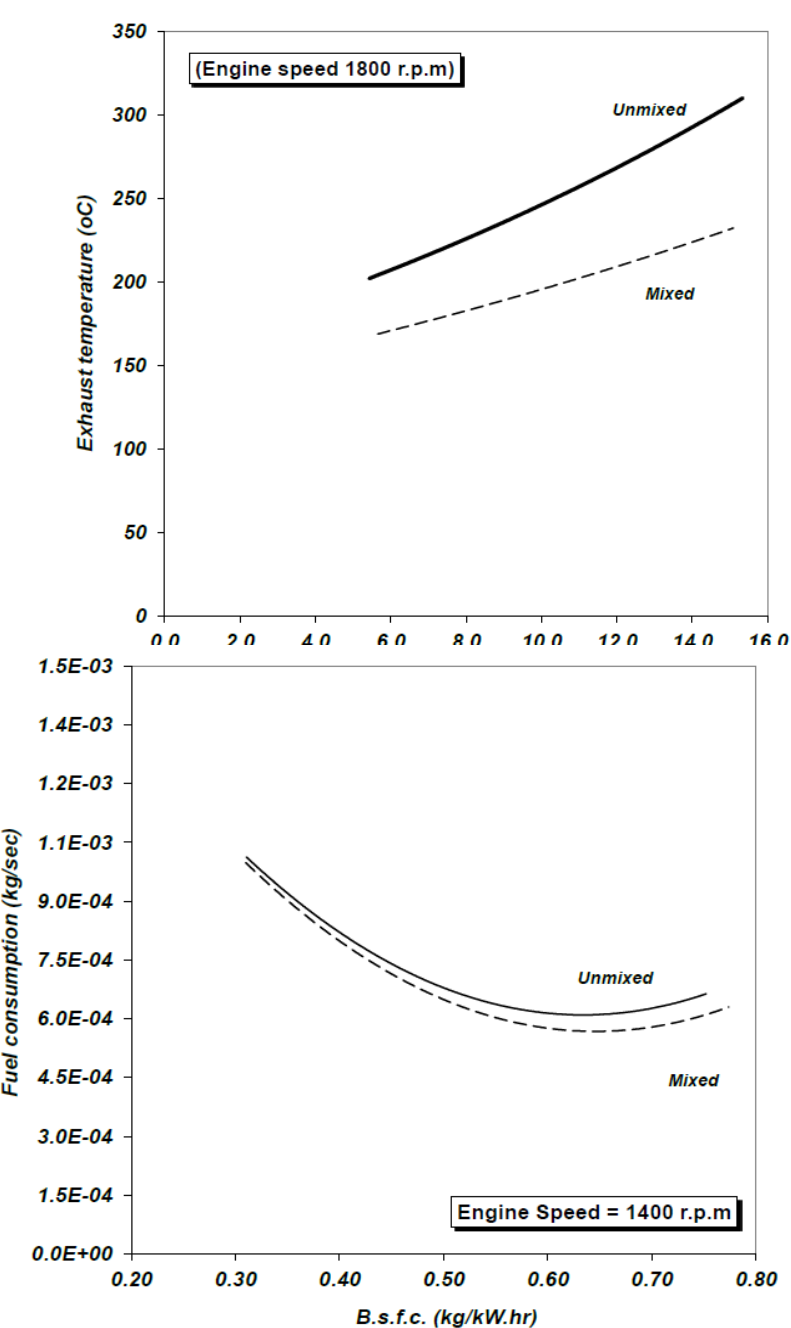

Fig. (22): relation between fuel consumption and brake specific fuel consumption for both mixed and unmixed fuel at $\mathrm{N}=1400 \mathrm{rpm}$ 


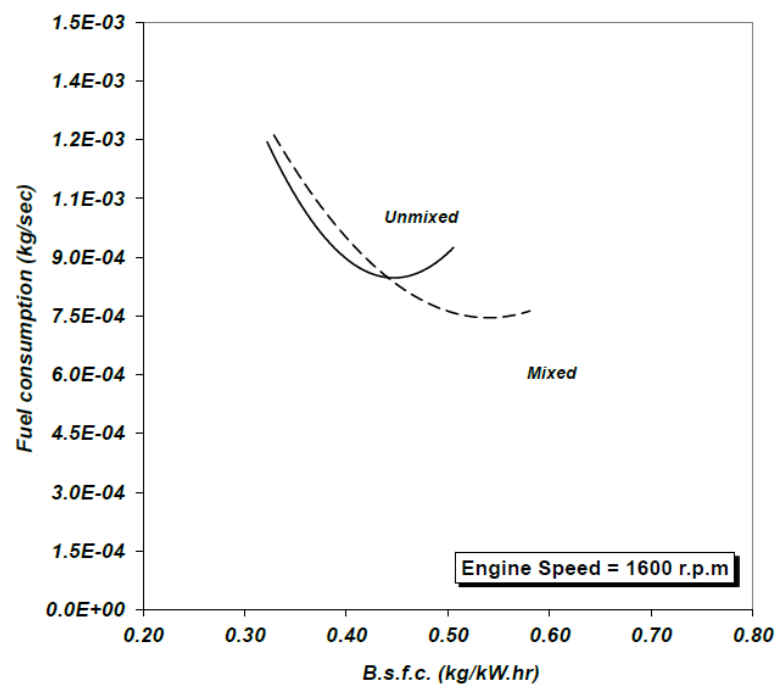

Fig. (23): relation between fuel consumption and brake specific fuel consumption for both mixed and unmixed fuel at $\mathrm{N}=1600 \mathrm{rpm}$

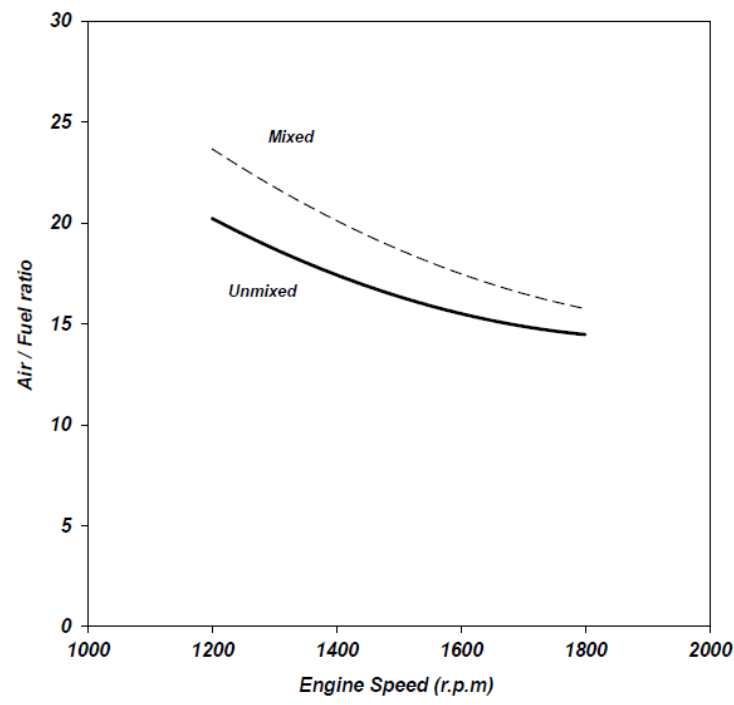

Fig. (25): relation between $A / F$ ratio \& engine speed for mixed and unmixed fuels

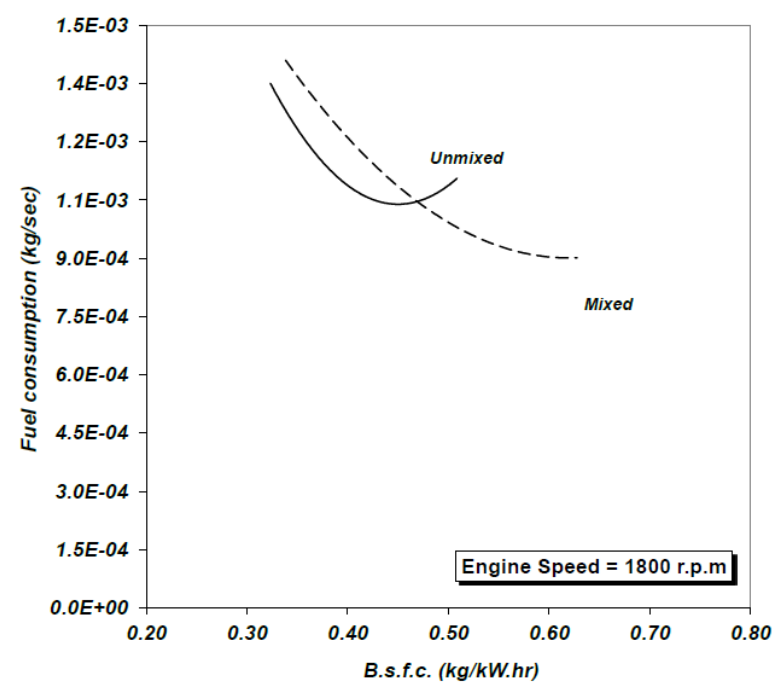

Fig. (24): relation between fuel consumption and brake specific fuel consumption for both mixed and unmixed fuel at $\mathrm{N}=1800 \mathrm{rpm}$

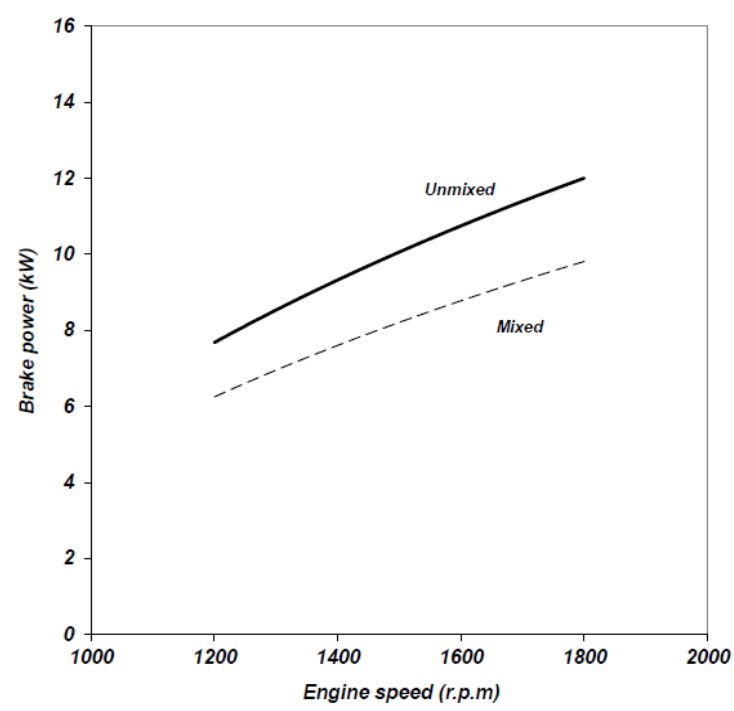

Fig.(26): relation between brake power and engine speed for both mixed \& unmixed fuel

\section{CONCLUSION}

The general results obtained from the experiments can be summarized as follows:

- Addition of 5\% Naphtha with $90 \%$ pure gas oil and $5 \%$ Ethanol are the best blending ratio for the mixture to get positive results.

- In mixing fuel by stirring and motion then leaving over for 48 hours will avoid separation of blending elements.
- Exhaust temperature is lower in mixed fuel than that of unmixed.

The fuel consumption is lower in mixed fuel due to lower economic point resulted in which less fuel consumption against larger brake power can gain.

- The A/F ratio is higher in mixed fuel.

- Brake thermal efficiency is higher in mixed fuel and in all speeds. 


\section{REFERENCES}

- Wang,Y.D., Al-Shemmeri T., Eames P., Mcmullan J., Hewitt N., and Huang Y. "An experimental investigation of the performance and gaseous exhaust emissions of a diesel engine using blends of a vegetable oil". Applied thermal engineering, 26, 1684-91, 2006.

- Tadashi Young. "Low carbon build up, low smoke and efficient diesel operation with vegetable oil by conversion to monoesters and blending of diesel or alcohols". SAE 841161, 1984.

- Can Has-imoglu, Murat Ciniviz, I'brahim O" Zsert, Yakup I'c-ingu" r, Adnan Parlak and M.Sahir Salman. "Performance characteristics of a low heat rejection diesel engine operating with biodiesel'. Renewable Energy, 33, 1709-1715, 2008.

- Deepak Agarwal, Shailendra Sinha and Avinash Kumar Agarwal. "Experimental investigation of control of NOx emissions in biodiesel-fueled compression ignition engine". Renewable Energy, 31, 2356-2369, 2006.

- Balamurugan T., Nalini R.. "Effect of blending alcohol with diesel on performance, combustion and emission characteristics of four stroke diesel engine- an experimental study".
International journal of ChemTech Research, vol.6. No. 1, 750-762, 2014.

- Atilla Bilgin, Orhan Durgun, Zehra Sahin. "The effects of Diesel - Ethanol Blends on diesel engine performance". Energy sources, 24: 431440, 2002.

- A.Pannirselvam, M.Ramajayam, V.Gurumani, S.Arulselvan and G. Karthikeyan, "Experimental studies on the performance and emission characteristics of an ethanol fumigated diesel engine". International journal of engineering research and application, vol.2, issue2, 1519- 1527, 2012.

- Abu-Qudais M., Haddad O., Qudaisat M.. "The effect of alcohol fumigation on diesel engine performance and emissions". Energy Conversion and management 41, 389-399, 2000.

- Mathur M.L., Sharma R.P. "A course in Internal Combustion Engines". Dhanpat Rai \& Sons, Inc., Delhi, 1984.

يوّ خته

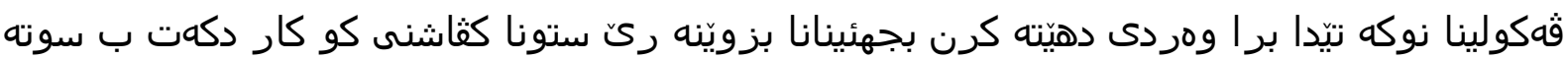

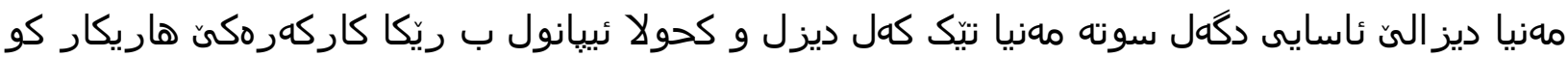

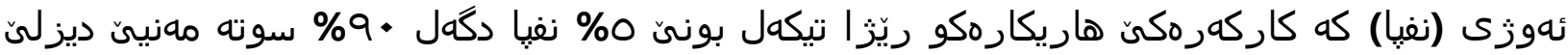

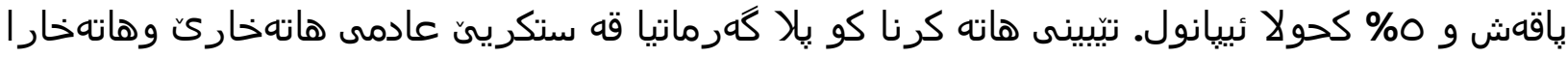

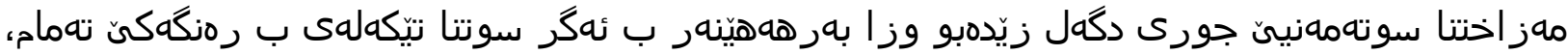

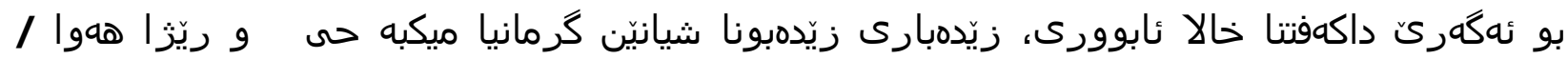

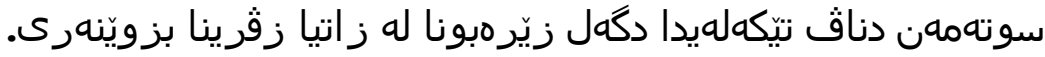

البحث الحالي تم فيه مقارنة أداء محرك الاحتراق الانضغاطاطي عملياً الذي يعمل بوقود الديزل

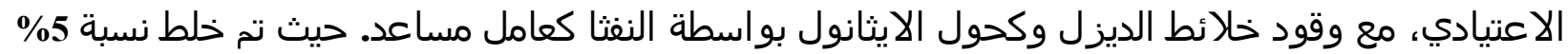

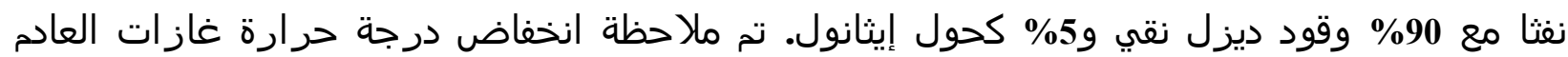

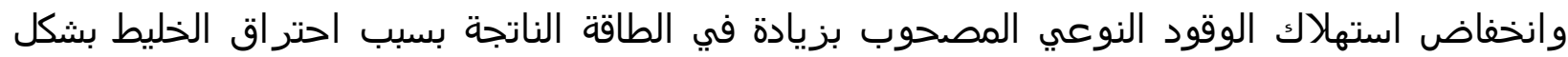

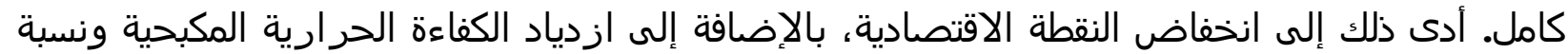
الهواء/الوقود في الخليط مع زيادة سرعة دوران المحرك، مما يدل على تحسين أداء المحرك التشغية التهيلي. 